\title{
Visitors' Experiences of Cluster Developments at Theme Parks in Malaysia
}

\author{
Salamiah A. Jamal ${ }^{1}$, Norliza Aminudin ${ }^{1}$, \& Norliza Abdul Rahman ${ }^{1}$ \\ ${ }^{1}$ Hotel Department, Faculty of Hotel \& Tourism Management, Universiti Teknologi MARA, Malaysia \\ Correspondence: Salamiah A. Jamal, Hotel Department, Faculty of Hotel \& Tourism Management, Universiti \\ Teknologi MARA, Malaysia. E-mail: salam383@salam.uitm.edu.my
}

Received: April 10, 2017

doi:10.5539/ass.v13n8p41
Accepted: May 3, $2017 \quad$ Online Published: July 25, 2017

URL: https://doi.org/10.5539/ass.v13n8p41

\begin{abstract}
The spread of social and financial advancement in business environment of developing countries has instigated various expansion approaches, ranging from industry agglomeration to industry clusters, which refers to groups of interrelated firms located in a defined geographical area. Firms or companies that participate in cluster developments benefit from each other in terms of sharing the same territory, infrastructure and services, which has prompted encouraging responses from many industries, including tourism. The Malaysian government licenses intellectual property as well and promotes it to further advance the tourism industry in the country, particularly in the theme park sector. There are 16 theme parks and water parks in the country and 10 more are reported being launched in upcoming years. However, there have also been several closures among theme parks in recent years. Many previous studies have looked into the development of theme parks, focusing on many aspects, including cluster policy and concept, competitiveness, sustainability, safety and security, yet research that looks into cluster development specifically in Malaysia is still scant. The main purpose of this study is to examine whether visitors' experiences of cluster developments at theme parks in Malaysia have a significant relationship to their intentions to revisit the park. A survey of 312 Malaysian theme park visitors was carried out using a questionnaire, and it concluded that visitors' experiences of all cluster development dimensions had a significant relationship to their intentions to revisit the park. This finding contributes to an understanding of the importance of visitors' experiences in theme park tourism and what this means to the tourism industry in the future.
\end{abstract}

Keywords: cluster development, theme park, visitor, intention to revisit, Malaysia

\section{Introduction}

\subsection{Preamble}

In the past, the business environment in developing countries has taken various approaches to spread social and financial advancement in the areas they are located in (Altman \& Berman, 2011). Therefore, there are many different approaches for regional economic development, ranging from industry agglomeration to industry clusters (Bekele \& Jackson, 2006). Porter (2000) stated that industry clusters of like-minded businesses and talents in a specific geographic area have existed for centuries in cities, which became known for their specialisations. An industry cluster is defined as a geographically proximal group of interconnected enterprises associated with institutions in a particular field, linked by commonalities and complementarities (Porter \& Kramer, 2011). To simplify, a cluster refers to a group of interrelated firms located in a definite geographical range (Talib \& Hassan, 2015). Nordin (2003) stated that the cluster development concept can be applied to many businesses and sectors. UNIDO (2016) pointed out that usually companies that form clusters are partaking of the same territory, infrastructure, services and, in numerous cases, shared cultural identity and social values.

A lot of countries and regions have acknowledged that the tourism industry is a mechanism to boost their economy (Kim \& Wicks, 2010). The Malaysian government, as well, licenses intellectual property and uses it to develop the tourism industry, particularly theme parks (IAAPA, 2015). Therefore, Malaysia is a good example of defining tourism clusters at the regional level including of the rapid growth of the theme park industry. According to a Themed Entertainment Association (TEA) report in 2016, attendance at Asian-Pacific theme parks increased 6.9\% from 2015 to 2016, while visitor attendance was 122.5 million in 2015 and 130.9 million in 2016. IAAPA (2015) forecast that visitor spending in Malaysia's theme parks will increase from 140 billion in 
2014 to 196 billion by 2019. Looking at the cumulative growth of the theme park sector and the large volume of research on the subject, a critical review of past and current research is necessary (Shan \& Zhang, 2016). Given the increasing number of parks, the survival of theme parks has become a more challenging issue.

\subsection{Statement of the Problem}

Malaysia is fast becoming the theme park capital of Southeast Asia, with 16 theme parks and water parks throughout the country, and at least 10 more reported being launched in upcoming years (CNN, 2015). The most recent project was Legoland Malaysia, which receives regular visitors from Singapore and Malaysia as well as tourists from around the world (Iskandar Malaysia, 2012). Next in the pipeline will be 20th Century Fox World in the Genting Highlands and the Movie Animation Park Studios (MAPS) in Perak, featuring numerous attractions, including a DreamWorks Adventure Zone projected to be complete by the end of 2017 (Hogan, 2015) However, despite the mushrooming of new theme parks in the country, there are also significant numbers of theme park closures (e.g. Desa Water Park, Mimaland Malaysia, Wet World Wild Adventure Park Batu Feringgi, Sand City Water Park Tanah Merah) (Anonymous, 2015; The Star, 2016; 2015; 2013). While the benefit of tourism cluster has now expanding in every sort of public space, ranging from airports and malls to office buildings, hotels and restaurants (Margaret, 2002), the cluster development approach of Malaysian theme parks has yet to be explored.

Since the sustainability of theme parks very much depends on cluster development, the existence of theme parks should take a longer-term perspective in order to create an appropriate balance between economic returns and environmental conservation to achieve sustainable development (Ho, 2006). And whether the competitiveness of each theme park significantly depends on the cluster development of the area has yet to be proved (Kim \& Wicks, 2010). Although many previous studies on theme parks have been carried out in relation to safety and new technologies (Zheng, 2011), the operating performance of theme parks (Lee, Ting \& Chen, 2011), visitors' satisfaction (Romli, Ahmad, Kassim \& Ibrahim, 2015) visitor behaviour (Nuryyev \& Achyldurdyyeva, 2015), the effect of co-branding (Cornelis, 2010), guest perception (Milman, 2013) and customer information management (Hervás, Rodon, Planell \& Sala, 2011), research on theme park cluster development in Malaysia is still scant (Talib \& Hassan, 2015). In addition, the visitor experience with cluster development at theme parks and their intentions to revisit have not been studied in the Malaysian context. Therefore, the objectives of this study are as follows:

- to identify the most developed dimension of cluster development in the context of theme parks from the perspective of visitors; and

- to examine the relationship between visitors' experiences with cluster development and their intentions to revisit.

\subsection{Literature Review}

\subsubsection{Cluster Concept}

Kim \& Wicks (2010) introduced a process, called global competitiveness, pertaining to cluster development in that part of the tourism industry that embraces a wide range of aspects, namely, centre assets and attractions, destination administration, correlative conditions and request conditions. As participating in clusters should result in many positive effects, a recent study reported that $65 \%$ of the businesses believe that their cluster participation heightens the level of knowledge and technology in their sector (Quercus Group, 2017). Clusters are not only supposed to enhance the competitiveness of firms and entrepreneurship activities in a distinct region (Sölvell, 2009) but also provide an infrastructure that attracts specialised suppliers and high-skilled workers, enhance technological and knowledge, and lower transportation costs between regionally concentrated firms (Lublinski, 2003). The above are in line with what has been defined in earlier cluster theory: a geographic awareness concerning interconnected companies or institutions working on a common subject and enterprise yet the corporations are each interrelated and supplementary (Porter, 2000).

\subsubsection{Cluster Development Attributes}

The principal elements of the tourism cluster on an individual and framework level are the cluster supports towards the aggressiveness of tourism destinations. The cluster model of Crouch and Ritchie (1999) suggested that tourism destinations' competitiveness is determined by four major components: (1) qualifying determinants (location, dependencies, safety and cost), (2) destination management (resource stewardship, marketing, organisation, information and service), (3) core resources and attractors (physiography, culture and history, market ties, the mix of activities, special events and tourism superstructure) and (4) supporting factors and resources (infrastructure, accessibility, facilitating resources and enterprise). At a later stage, Cracolici, Nijkamp 
\& Rietveld (2008) added the efficiency component to the model to measure tourism site competitiveness. Based on the above models, Kim and Wicks (2010) recently proposed a revised tourism cluster development model that incorporates centre assets and attractions, destination administration, correlative conditions and request conditions. This comprehensive model takes into account the importance of transnational corporations, the emphasis on networks between all cluster actors and the division between cluster actors and the conditions of the business sector.

\subsubsection{Theme Park Cluster Development}

Yabing (2007) highlighted that the theme park spatial economic structure is mainly composed of theme tourism clusters around space structures and the structure of land. The study found that theme park tourism passenger flowing directly results in the formation of theme park clusters and indirectly influences theme park surrounding area to form agglomeration and causes real estate prices to rise. Chu (2008) analysed the brand advantage of the big four spatial agglomeration Hollywood film and television creative industry and developed the cluster internal regularity of creative industry management. Cluster development was also evidenced in film and theme park roots (Wen \& $\mathrm{Li}, 2008$ ).

\subsubsection{Intentions to Revisit}

Tourists' intentions to revisit can be viewed as an individual's anticipated future travel behaviour, and the concept of intention to revisit has been considered a main factor highly correlated with actual behaviour (Chang, 2013). On the other hand, repeat visitation is a natural phenomenon for mature holiday destinations (Alegre \& Cladera, 2006). An understanding of what first-time and repeat visitors are looking for and how they evaluate a destination service's performance is warranted in order to develop programs to convert first-time visitors into repeat visitors, to maintain the existing repeat visitor base and, consequently, to enhance sales and profits (Yuksel (2000a). Hence, ensuring repeat visitations is an important measure to maintain the competitiveness of these destinations (Wang, 2016).

Mitchell (2006) demonstrated that past tourism experiences and memories are influential in the future behavioural intentions of tourists. A memorable tourism experience is more likely to result in a future repeat visitation and recommendations to others (Wang, 2016). Nevertheless, how theme park cluster development influences the visitor experience has yet to be explored. Thus, this study fills in this gap.

\subsubsection{The Relationship between Visitor Experience and Intentions to Revisit}

So as to sustain competitiveness, planning a memorable experience to entice tourists to revisit a destination year after year should be a key mission (Chang, 2013). Thus, in modern theme parks, a principle unifies the structure and the organisation of the park is through creating memorable experience; as result, many theme parks attempt to incorporate the visitor experience into almost every aspect of the park's operation (Milman, 2007). Lillestol, Timothy \& Goodman (2015) suggested that theme parks' competitiveness also depends on the currency and ease of management mechanisms and the promotion of beneficial against competitors. Thus, any effort that captivate repeater is the one important way to maintain the competitiveness of these destinations (Huang \& Hsu, 2009). The results from a study by Wang (2016) indicated that university students' memorable tourism experiences positively influenced their intention to revisit and intention to recommend a destination for spring break, demonstrating that the more memorable the tourism experience, the higher the intention to revisit and to recommend the destination to others. Therefore, based on these studies, a hypothesis is suggested.

$\mathrm{H}_{1}$ : There is a significant relationship between visitors' experiences in cluster developments and their intentions to revisit in the context of theme parks.

\subsubsection{The Relationship between Visitor Experience and Intentions to Revisit}

While the other component is critical to success and profitability, the information sources and knowledge on destinations is often the main reason why tourists choose destinations (Crouch \& Ritchie, 2003). Moreover, a study from Dayour and Adongo (2015) contended that satisfied tourists are more likely to revisit; it is for that reason vital for service providers in of any kind capacity to ensure that tourists are satisfied with the services offered to them so as to generate repeat visits; therefore, this requires destination management to be effective. Cho, Byun \& Shin (2014) claimed that repeat visitors may be also influenced by these positive information sources, and that tourist destination promotion will result in other economic incentives in rural areas. Information sources and tourist destination promotion were part of the destination management's subfactors.

A destination with an abundance of core resources and attractors but a lack of adequate supporting factors and resources or known complementary conditions (Kim \& Wicks, 2010) may find it very difficult to develop its tourism industry; however, these factors may significantly shape the realisation of tourism potential at the 
destination, particularly theme parks. Some demand conditions' criteria are awareness about the destination and the good image of the destination itself (Crouch \& Ritchie, 2003). Thus a study by Pratminingsih, Rudatin and Rimenta (2014) found that the more positive a destination's image and the more aware of the destination visitors were, they more likely they were to revisit. As a result of these studies, the below hypotheses are proposed:

$\mathrm{H}_{1 \mathrm{a}}$ : There is significant relationship between core resources and attractions and intentions to revisit in the context of theme parks.

$\mathrm{H}_{1 \mathrm{~b}}$ : There is significant relationship between destination management and intentions to revisit in the context of theme parks.

$\mathrm{H}_{1 \mathrm{c}}$ : There is significant relationship between complementary conditions and intentions to revisit in the context of theme parks.

$\mathrm{H}_{1 \mathrm{~d}}$ : There is significant relationship between demand conditions and intentions to revisit in the context of theme parks.

\section{Research Methodology}

\subsection{Research Design}

A structured quantitative approach was employed to achieve the objective of examining the relationship of cluster development dimensions to intentions to revisit. Various dimensions constituting the cluster development of a theme park and revisitation behaviour in a tourism context that were identified in previous research were incorporated into a structured-questionnaire survey to collect the primary data.

\subsection{Population and Sample}

The study population consisted of Malaysia theme parks visitors. The estimated population was 9,665,333, after estimating annual visitor attendance at three theme parks in Malaysia included in "The Theme Index and Museum Index: The Global Attractions Attendance Report" (TEA, 2016). Following a suggestion by Krejcie and Morgan (1970), the sufficient sample size for this study was determined to be 384. As the sample frame for this study is not available, a nonprobability sampling technique and purposive or judgment sampling design were used. An answer to a screening question on a recently visited theme park in Malaysia was required from the respondents.

Based on the $30 \%$ response rate rule of thumb, 1100 questionnaires were distributed in order to achieve a sufficient sample. The survey was conducted at selected theme park exits, where visitors were requested to fill out the questionnaire immediately after completing their theme park visit, thus avoiding the influence of memory and in order to obtain current information. Finally, 317 were collected: 5 were missing data and only 312 (a $62.4 \%$ usable response rate) were coded and used for data analysis. This response rate is similar to Tobin, Thomson, Radhakrishna \& LaBorde (2012), who used mixed-mode surveys in their study while adapting to budget constraints. In addition, Kidder (1981) stated that $50 \%$ is regarded as an acceptable response rate in social research postal surveys.

\subsection{Survey Instrument}

The questionnaire consisted of six sections: Section A measured respondents' demographic profiles, Section B measured respondents' experiences with core resources and attractions at the theme park, Section $\mathrm{C}$ measured respondents' experiences with destination management, Section D measured respondents' experiences with complementary conditions, Section E measured respondents' experiences with demand conditions and Section F measured respondents' intentions to revisit. A five -point Likert scale was used as the response format for all variables: 1 = strongly disagree, $2=$ disagree, $3=$ neutral, $4=$ agree, $5=$ strongly agree. Items included the aspect of visitors' experiences with cluster development dimensions that included core resources and attractions, destination management, complementary conditions and demand conditions. All items were adapted from the existing literature (Crouch \& Ritchie, 2003). The core resources and attractions dimension contained 7 items, and the destination management dimension embraced 8 items, while the complementary conditions dimension consisted of 4 items and the demand conditions dimension had 7 items. All these dimensions were adapted from Kim and Wicks (2010). The intention-to-revisit construct included 7 items adopted from Petrick, Backman \& Carolina (2002).

\subsection{Data Analysis}

To generate meaningful results, data were analysed by SPSS version 22. For further implications and discussions, various statistical analysis techniques, including descriptive analysis, reliability tests, factor analysis (EFA) and multiple regressions, were employed with respect to the objectives. 


\section{Findings}

\subsection{Respondents' Demographic Profile}

Among the 312 respondents, the majority were female $(60.9 \%$ vs. $39.1 \%$ male). The respondents were employees $(72.5 \%)$ students $(14.4 \%)$, unemployed $(11.2 \%)$ and employers $(1.8 \%)$. Most of the respondents were $24-39$ years old $(86.2 \%)$, followed by those under $24(9.0 \%)$, those $40-55$ years old $(3.8 \%)$ and those over 55 $(0.6 \%)$. With regard to annual income, $57.7 \%$ of respondents earned USD $\$ 0-25,999,34.6 \%$ had an income of USD \$26,000-\$51,999, 4.5\% earned USD \$52,000-74,999 and 3.2\% had an income over USD \$75,000. In terms of nationality, $98.1 \%$ of the respondents were Malaysian and $1.9 \%$ was international visitors. The travel purposes were leisure $(75.3 \%)$, followed by meeting friends and relatives $(14.4 \%)$, business purposes $(2.2 \%)$ and other reasons $(8.0 \%)$. Generally, the respondents' education levels were postgraduate $(16.0 \%)$, undergraduate $(71.5 \%)$, and secondary education (12.5\%).

The theme park with the most favourable rating was Genting Malaysia Berhad, which scored $20.5 \%$, followed by Sunway Lagoon Sdn Bhd with 18.9\%, Bukit Gambang Water Park (13.8\%), Legoland Malaysia Resort (12.2\%), Bukit Merah Laketown Resort (9.9\%), Berjaya Times Square Theme Park (8.7\%), A'Famosa Resort (7.1\%), Desa Water Park (3.8\%), Melaka Wonderland (2.6\%), Wet World (1.6\%) and Bayou Lagoon Park Resort at 1.0\%. As for which theme parks had been visited the most, Genting Malaysia Berhad was highest (33.3\%), followed by Sunway Lost World Water Park (26.7\%).

\subsection{Overall Mean Score for the Cluster Development Dimensions}

Table 1 shows visitors' experiences with each dimension of cluster development in Malaysian theme parks: core resources and attractions, destination management, complementary conditions and demand conditions. The result indicates that the most developed dimension of cluster development from visitors' experiences and perspectives is the complementary conditions ( $\mathrm{M}=4.01, \mathrm{D})$, followed by demand conditions $(\mathrm{M}=4.01, \mathrm{E})$ and destination management $(M=3.79, C)$. However, the core resources and attractions of the theme park were ranked lowest $(\mathrm{M}=3.04, \mathrm{~B})$.

Table 1. Reported Overall Mean Scores for Cluster Development Dimensions

\begin{tabular}{cccc}
\hline Scales & $n$ & Mean & SD \\
\hline Section B: Core Resources \& Attractions & 312 & 3.04 & 0.8375 \\
Section C: Destination Management & 312 & 3.79 & 0.7945 \\
Section D: Complementary Conditions & 312 & 4.06 & 0.7073 \\
Section E: Demand Conditions & 312 & 4.01 & 0.7444 \\
\hline
\end{tabular}

Scale: 1 = Strongly Disagree, $2=$ Disagree, $3=$ Neutral, $4=$ Agree, $5=$ Strongly Agree

\subsection{Hypotheses Testing}

$\mathrm{H}_{1}$ : There is a significant relationship between visitors' experiences with cluster development and their intentions to revisit in the context of theme parks.

A linear regression analysis was carried out to test the hypothesis to determine whether visitors' experiences with theme park cluster development (core resources and attractions, destination management, complementary conditions and demand conditions) has a significant influence on their intentions to revisit. As seen in Table 2, it was found that visitors' experiences with theme park cluster development significantly and positively contributed to their intentions to revisit ( $\mathrm{p}$-values $=0.000$ ). Thus, $\mathrm{H}_{1}$ is accepted.

Table 2. Linear Regressions of the Cluster Development Dimensions and Intentions to Revisit

\begin{tabular}{|c|c|c|c|c|c|}
\hline \multicolumn{6}{|c|}{ Coefficients $^{\mathrm{a}}$} \\
\hline \multirow[t]{2}{*}{ Model } & \multicolumn{2}{|c|}{ Unstandardized Coefficient } & \multicolumn{2}{|c|}{ Standardized Coefficient } & \multirow[b]{2}{*}{ Sig. } \\
\hline & $\mathrm{B}$ & Std. Error & Beta & $\mathrm{t}$ & \\
\hline $\begin{array}{ll}1 & \text { (Constant) }\end{array}$ & 7205.15 & 1850.25 & & 4.604 & 0.000 \\
\hline Cluster Development & 0.465 & 0.064 & 0.701 & 9.615 & 0.000 \\
\hline \multicolumn{6}{|l|}{ Core Resources and Attractions } \\
\hline \multicolumn{6}{|l|}{ Destination Management } \\
\hline Complementary Conditions & & & & & \\
\hline
\end{tabular}


Demand Conditions

a. Dependant Variable: Intention to Revisit

\section{Discussion and Conclusion}

This study examined the relationship between cluster development dimensions and intentions to revisit in theme park settings. This relationship was studied from the perspective of visitors to selected theme parks in Malaysia. Understanding this relationship is important since theme parks are set up to generate profits through winning visitors' hearts when visiting as well as through revisits. This is obviously acquired by providing varieties of facilities, great services and other elements, including in cluster development dimensions. It is recognised that the resiliency and survival of theme parks depends on cluster development, which is not only maintained by theme park operators but also by the surrounding organisations and businesses in order to sustain or improve their success and competitiveness by having repeat visitors.

Successful cluster development of a theme park should further affect visitors' experiences and subsequently increase their repeat visits. The level of overall satisfaction with holiday experiences had the greatest impact on the intention to revisit the same destination (Cho et al., 2014). The finding of this study shows that cluster development dimensions, including the core resources and attractions, destination management, complementary conditions and demand conditions, significantly influence the intention to revisit among visitors and generate a positive impact on theme parks' operational survival.

From the managerial perspective, this study highlighted the positive experience on the most developed dimension (complementary conditions) as well as the least developed dimension (core resource and attractions). Therefore, when theme park operators reposition their business, they should emphasise improving the element that is still lacking from the perspective of visitors. Furthermore, theme park operators should attract visitors with an increased number of rides that cater to various segments, ranging from adventurous rides to those for kids. This finding should aid not only theme park operators but also other organisations, such as food and beverage operators, hoteliers and other tourism-related firms in the surrounding area to better understand visitors' needs and preferences in order to contribute to their theme park business's survival.

A limitation encountered in this work and an implication for future research must be noted. This study adopted the tourism cluster model Kim \& Wicks (2010) that includes four dimensions. As this model is applicable to general tourism, future studies could adopt an experimental approach to proposed specific dimensions that specifically focus on theme park settings so as to increase the accuracy of the findings.

\section{References}

Alegre, J., \& Caldera, M. (2006). Repeat visitation in mature sun and sand holiday destinations. Journal of Travel Research, 44(3), 288-297.

Altman, D., \& Berman, J. (2011). The Single Bottom Line Daniel Altman. Jonathan Berman. June 13, 2011.

Anonymous. (2015). Percutianbajet.com. Retrieved September 23, 2016, from http://www.percutianbajet.com/senarai-taman-tema-di-seluruh-malaysia

Babbie, E. R. (1973). Survey research methods. Belmont, CA: Wadsworth.

Babbie, E. R. (1990). Survey Research Methods (2nd ed.). Wadsworth Publishing Company, Belmont, California.

Bekele, G. W., \& Jackson, R. W. (2006). Theoretical Perspectives on Industry Clusters, 1-26.

Chang,L. (2013). Influencing factors on creative tourists revisiting intentions:the roles of motivation, experience.

Cho, H., Byun, B., \& Shin, S. (2014). An Examination of the Relationship between Rural Tourists' Satisfaction, Revisitation and Information Preferences: A Korean Case Study. Sustainability, 6(9), 6293-6311.

Chu, J. (2008). Disney took a worldwide network of creative industrialization strategy management. Journal of World Geography Research, (4), 115-125.

Cornelis, P. C. M. (2010). Effects of co-branding in the theme park industry: a preliminary study. International Journal of Contemporary Hospitality Management, 22(6), 775-796.

Crouch, G. I., \& Ritchie, J. R. B. (2003). Modelling Destination Competitiveness A Survey and Analysis of the Impact of Competitiveness Attributes National Library of Australia Cataloguing in Publication Data. Australia: The Sustainable Tourism Cooperative Research Centre.

Crouch, G., \& Ritchie, J. (1999). Tourism, competitiveness, and societal prosperity. Journal of Business Research, 
44(3), 137-152

Dayour, F., \& Adongo, C. A. (2015). Why They Go There: International Tourists' Motivations and Revisit Intention to Northern Ghana, 4(1), 7-17.

Guo, W., \& Wang, L. (2008). The Film And Television Theme Park Tourism Development Mode Of "Symbiosis" Research And Industrial Communities Demands. Journal of Travel Research, 4(23), 64-71.

Hervás, M. a, Rodon, J., Planell, M., \& Sala, X. (2011). From theme park to resort: customer information management at Port Aventura. Journal of Information Technology Teaching Cases, 1(2), 71-78. http://doi.org/10.1057/jittc.2011.9

Hogan Jr, D. (2015). Malaysia's greatest theme parks - CNN. Retrieved from http://edition.cnn.com/2015/11/27/travel/malaysia-theme-parks/

Huang, S. S., \& Hsu, C. H. (2009). Effects of travel motivation, past experience, perceived constraint, and attitude on revisit intention. Journal of Travel Research.

IAAPA - The International Association of Amusement Parks and Attractions. (2016). http://www.iaapa.org/

Iskandar Malaysia (2012). Welcome to Iskandar Investment Bhd. [online] Available at: http://www.iskandarinvestment.com/value-creation/cluster-development-strategy/tourism/

Kim, N., \& Wicks, B. E. (2010). Rethinking Tourism Cluster Development Models for Global Competitiveness. International CHRIE Conference-Refereed Track, 28.

Krejcie, R. V., \& Morgan, D. W. (1970). Determining Sample Size for Research Activities Robert. Educational and Psychological Measurement, 38(1), 607-610.

Li, H. (2014). Analysis of formation mechanism of revisit intention: Data from East China. In 2014 International Conference on Global Economy, Commerce and Service Science (GECSS-14). Atlantis Press.

Li, Y. (2007). Theme park tourist passenger space economic effect analysis. Industrial Observations, (34), 88-89.

Lillestol, T., Timothy, D., \& Goodman, R. (2015). Competitive strategies in the US theme park industry: a popular media perspective. International J. of Culture, Tourism and Hospitality Research, 9(3), 225-240.

Lublinski, A. E. (2003). Does geographic proximity matter? Evidence from clustered and non- clustered aeronautic firms in Germany. Regional Studies, 37(5), 453-467.

M.A.A.T.F.A. (2016). Malaysian Association of Amusement Themepark \& Family Attractions. Maatfa.com.my.

Margaret, J. K. (2002). The Theme Park: Aspects of Experience in a Four-Dimensional Landscape. Center for Cultural Studies \& Analysis, 34(2).

Milman, A. (2007). 13 Theme Park Tourism and Management Strategy. Tourism Management: Analysis, Behaviour, and Strategy, 218.

Milman, A. (2013). Guests' perception of staged authenticity in a theme park: An example from Disney's Epcot's World Showcase. Tourism Review, 68(4), 71-89.

Nogales, E. G. (2010). Agro-based clusters in developing countries: staying competitive in a globalized economy.

Nulty, D. D. (2008). The adequacy of response rates to online and paper surveys: what can be done? Assessment \& Evaluation in Higher Education, 33(3), 301-314.

Nuryyev, G., \& Achyldurdyyeva, J. (2015). Visitor behaviour and profitability of Turkmenbashi World of Fairytales in Turkmenistan. Journal of Hospitality and Tourism Technology, 6(1), 73-88.

Petrick, J. F. (2004). The Roles of Quality, Value, and Satisfaction in Predicting Cruise Passengers' Behavioral Intentions. Journal of Travel Research 42(4), 397-407.

Petrick, J. F., Backman, S. J., \& Carolina, S. (2002). An Examination of the Construct of Perceived Value for the Prediction of Golf Travelers ' Intentions to Revisit. Journal of Travel Research, 41.

Porter, M. E. (1990). The competitive advantage of nations. New York: Free Press. 855 p

Porter, M. E. (1996). Competitive Advantage, Agglomeration Economies, and Regional Policy. International Regional Science Review, 19(1-2), 85-90.

Porter, M. E. (1998). Clusters and the new economics of competition. Harvard Business Review, 77-90

Porter, M. E. (1998a). On competition. Boston: Harvard Business School Press. 544 p. 
Porter, M. E. (1998b). Location, clusters and the 'new' micro- economics of competition. Business Economics $33(1), 7-17$

Porter, M. E. (1998c). Clusters and the new economics of competition. Harvard Business Rev., Nov-Dec, 77-90.

Porter, M. E. (2000). Location, competition, and economic development: local clusters in global economy. Sage: Economic Development Quarterly, 15-34.

Porter, M. E., \& Kramer, M. R. (2006). Strategy \& society: The link between competitive advantage and corporate social responsibility. Harvard Business Review, 84(12), 78-92.

Porter, M. E., \& Kramer, M. R. (2011). Creating shared value. Harvard Business Review, 89(1-2).

Pratminingsih, S. A., Rudatin, C. L., \& Rimenta, T. (2014). Roles of Motivation and Destination Image in Predicting Tourist Revisit Intention: A Case of Bandung - Indonesia, 5(1).

Quercus Group. (2017). Businesses Clearly Benefit from Cluster Participation. Retrieved June 2, 2017, from http: //www.quercus-group.com/single-post/2017/04/07/Businesses-clearly-benefit-from-cluster-participation

Richardson, J. T. E. (2005). Instruments for obtaining student feedback: a review of the literature. Assessment \& Evaluation in Higher Education, 30(4), 387-415.

Robinson, J. P., Shaver, P. R., \& Wrightsman, L. S. (1991). Criteria for scale selection and evaluation. Measures of personality and social psychological attitudes, 1(3), 1-16.

Romli, S. M., Ahmad, A., Kassim, A., \& Ibrahim, R. (2015). Determining visitors'satisfaction in theme parks: a case from kuala lumpur, Malaysia, 323-332.

Shan, E., \& Zhang, G. (2016). Characterizations of the position value for hypergraph communication situations, (1988), 1-16.

Sölvell, Ö. (2009). Clusters - Balancing Evolutionary and Constructive Forces (2nd ed.). Ivory Tower Publishers, Stockholm.

Talib, N. A., \& Hassan, I. (2015). State-led cluster development initiatives: a brief anecdote of multimedia super corridor, 34(5), 524-535. http://doi.org/10.1108/JMD-02-2014-0011

TEA. (2016). Theme Index and Museum Index: The Global Attractions Attendance Report.

The Star (2013). Park in the sea runs into a storm - Nation | The Star Online. [online] Available at: http://www.thestar.com.my/news/nation/2013/12/30/park-in-the-sea-runs-into-a-storm/

The Star. (2015). MPHB Cap aborts Mimaland redevelopment deal - Business News | The Star Online. http:// www.thestar.com.my/business/business-news/2015/08/11/mphb-cap-aborts-mimaland-redevelopment-deal/

Thes Star (2016). The end of Desa Water Park - Community | The Star Online. [online] Available at: http://www.thestar.com.my/metro/community/2016/09/30/the-end-of-desa-water-park-dbkl-sells-land-to-pri vate-developer-which-plans-for-a-mixed-development/

Tobin, D., Thomson, J., Radhakrishna, R., \& LaBorde, L. (2012). Mixed-Mode Surveys: A Strategy to Reduce Costs and Enhance Response Rates. Journal of Extension, 50(6).

UNIDO. (2016). Industrial Development Report 2016 The Role of Technology and Innovation in Inclusive and Sustainable Industrial Development. United Nations Industrial Development Organization.

Wang, C. (2016). University Students' Travel Motivation, Memorable Tourism Experience and Destination Loyalty for Spring Break Vacation.

Wang, D. (2004). Tourist behaviour and repeat visitation to Hong Kong. Tourism Geographies, 6(1): 99-118.

Yuksel, A. (2000). Determinants of tourist satisfaction: Findings from Turkey. Paper presented at 5th Annual Graduate Education \& Graduate Students Research Conference in Hospitality and Tourism, Houston, USA

Zheng, T. (2011). A Mobile Architecture to Real-time Device Safety Monitoring of Amusement Park Ride Based on the Internet of Things. Contemporary Logistics, 5(5), 42-46.

\section{Copyrights}

Copyright for this article is retained by the author(s), with first publication rights granted to the journal.

This is an open-access article distributed under the terms and conditions of the Creative Commons Attribution license (http://creativecommons.org/licenses/by/4.0/). 